\title{
A Study on Development of Information and Communication Ethics Sensitivity Measurement for Elementary School Students
}

\author{
Woochun Jun* \\ Seoul National University of Education, Department of Computer Education, 06639, Korea
}

\author{
A R T I C L E I N F O \\ Article history: \\ Received: 17 November, 2019 \\ Accepted: 22 December, 2019 \\ Online: 22 January, 2020
}

Keywords:

ICT Ethics

Sensitivity

Elementary School Students

ICT Ethics

Software Education

\begin{abstract}
A B S T R A C T
With advances in information and communication technologies and internet technologies, we have many benefits in our daily life. Most people have smart devices and use them for their work and leisure, and so on. However, these advances technologies brought us various side effects such as copyright violation, internet addiction, cybercrimes, personal information infringement, etc. In order to cope with those side effects, it is very important to teach information and communication ethics to students as early as possible. In addition, in order to teach young students, first, their awareness to information and communication ethics needs to be tested. In the literature, most awareness test tools are to test knowledge of information and communication ethics. In fact, those awareness tools have not consider sensitivity for information and communication ethics. In this work, an extensive and integrated sensitivity measurement tool is developed. At first sensitivity measurement standards are developed based on literature review works. Many elementary school teachers and ICT education experts survey the initial standards. Finally, sensitivity measurement standards are finalized with 6 areas and 19 standards. It is hoped that the proposed standards will be very helpful to diagnose awareness of elementary school students for information and communication ethics.
\end{abstract}

\section{Introduction}

In current knowledge and information society, everybody can have benefits from advances in information and communication technologies(ICT), internet technologies, and smart technologies, etc. Those advances technologies have brought many benefits in our daily life. Now many people have their own personal and smart device such as tablet PC, and can access to news and stock prices as quickly as possible.

Education area is also changing very quickly. In current classrooms, many PC and mobile devices are used for students and teachers. Students can get information anytime anywhere and exchange their ideas with anybody in the world. Recently, with advanced VR(Virtual Reality) and AR(Augmented Reality) technologies, VR/AR-based education becomes popular[1,2,3].

As we have more benefits from advanced technologies, side effects form those technologies become serious. The typical side effects include personal information infringement, copyright violation, cybercrimes, hacking, and so on. Most countries provide precaution and cure plans for those who suffering side effects.

${ }^{*}$ Corresponding Author: Woochun Jun, Seocho Dong, Seocho Gu, Seoul, Korea, wocjun@snue.ac.kr

www.astesj.com

https://dx.doi.org/10.25046/aj050122
Usually costs for cure are tremendous. Thus, it is necessary to prevent those side effects as early as possible. The fundamental step to prevent is through education. Many countries provide education in the form of information and communication ethics education.

Recently robots are used in many areas as artificial intelligence and machine learning technologies have been developed. In this sense, ICT ethics education is extended to robot ethics education[4,5,6]. Robot ethics education can have big interest in the future as robots will be used more in industry and home. We need more fine and detailed principles and codes of ethics for more advanced robot.

In order to prevent and cure side effects from advanced technologies, it is very important to diagnose the status and awareness of students for ICT ethics. Based on correct diagnosis, it is possible to provide appropriate plans for precaution and cure. In the literature, awareness measurements are based on sole knowledge level of students. Knowledge on ICT ethics is important, however, sensitivity is more important. Sensitivity is defined formally in the next section. 


\section{W. Jun / Advances in Science, Technology and Engineering Systems Journal Vol. 5, No. 1, 169-173 (2020)}

The purpose of this work is to develop information and communication ethics sensitivity measurement standards for elementary school students. For this purpose, first, the initial sensitivity measurement standards are developed. Then, the proposed standards are surveyed by 30 elementary school teachers majoring information education. Finally, 19 sensitivity measurement standards with 6 areas are developed.

The rest of this paper is organized as follows. In Chapter 2, related works are introduced. In Chapter3, information and communication ethics sensitivity measurement standards for elementary school students are developed. In Chapter 4, statistical analysis is presented for those measurement standards. Finally, in Chapter 5, conclusions and further research issues are presented.

\section{Related Works}

\subsection{Definitions of Sensitivity}

Sensitivity is not formally defined in ICT ethics education. However, sensitivity is used for other ethics such as nursing ethics education. In nursing ethics education, moral sensitivity is defined as follows: Moral sensitivity is the ability to sensitize and detect conflict by sensitively identifying the problem surrounding the patient $[7,8]$.

In this paper, sensitivity in information and communication ethics is defined as follows: Sensitivity is the ability to judge responsibilities for information communication ethics sensitively and recognize the consequences of their actions

Sensitivity is more important than knowledge on ICT ethics since knowledge does not relate with actions. That is, someone knows danger of copyright violation, however, he or she can keep doing misconducts.

\subsection{Literature Review}

In the literature, there are some works on awareness measurement standards of ICT ethics for students[9,10,11,12,13]. However, these works are concerned with awareness on knowledge. It means that the awareness measurement standards do not reflect sensitivity.

In this paper, some of awareness standards are introduced as follows.

In [11], information and communication awareness measure standards are proposed. The standards are developed based on TPB(Theory of Planned Behavior) that is widely used to explain the major variables affecting a person's behavior. The standards consist of 4 areas(moderation, respect, responsibility, and participation) and 57 detailed standards.

In [12], a measurement tool is developed for test consciousness of information and communication ethics for middle school students. The tool consists of 5 areas, respect, justice, etiquette, freedom, and responsibility, respectively. The tool also has final 33 standards after statistical analysis. The following Table 1 shows areas and description for each area in their work.

In [13], ICEI (Information and Communication Ethics Index) is proposed. They insist that, if the purpose of information and communication ethics education is to prevent and remedy the behavior of the information and communication ethics so that the youth themselves can judge the ethical and unethical in the www.astesj.com information service society and do the right thing, then the development of the information and communication ethics index, which can measure the level of behavior of the information communication ethics problem of the youths, is more important than anything else. To ensure the reliability and feasibility of index developed in this study, it was applied to middle and high school students for an empirical analysis.

Table 1. Areas and Description of the Measurement Tool[12]

\begin{tabular}{|c|c|}
\hline Area & Description \\
\hline Respect & $\begin{array}{l}\text { It is a tribute to the noble values of } \\
\text { people and things in the information and } \\
\text { communication society. This evaluates } \\
\text { personal information protection and the } \\
\text { perception of oneself and others as } \\
\text { individuals. }\end{array}$ \\
\hline Justice & $\begin{array}{l}\text { This is a fair and correct way of doing } \\
\text { things in the information and } \\
\text { communication society. It evaluates the } \\
\text { extent to which rules and laws are } \\
\text { allowed to act properly and fairly. }\end{array}$ \\
\hline Etiquette & $\begin{array}{l}\text { This is the language etiquette and } \\
\text { greeting etiquette that should be } \\
\text { observed in the information and } \\
\text { communication society. This evaluates } \\
\text { the extent to which communication } \\
\text { etiquette is observed and others are } \\
\text { sought. }\end{array}$ \\
\hline Freedom & $\begin{array}{l}\text { This is a self-regulating and proactive } \\
\text { attitude that does not harm others in the } \\
\text { information and communication society. } \\
\text { This evaluates the degree of self-control } \\
\text { and self-regulation of one's will. }\end{array}$ \\
\hline Responsibility & $\begin{array}{l}\text { This is, in information and } \\
\text { communication society, responsibility } \\
\text { for its actions. It evaluates the extent of } \\
\text { the act of disseminating information and } \\
\text { the individual's own rules. }\end{array}$ \\
\hline
\end{tabular}

\section{Development of Evaluation Metrics for Learners}

\subsection{Design Principles}

The sensitivity measurement standards are developed with the following principles.

First, in order to develop comprehensive and integrated standards, overall aspects of education elements in ICT ethics education are considered and reflected.

Second, sensitivity is emphasized rather than knowledge and action for developing standards in this work. Sensitivity reflect interest and will to stop unfair action for elementary school students.

Third, too detailed standards such as standards depending on the current popular smart devices are not considered. This is 
because too detailed standards will be changed or removed depending on popularity of the device or technology.

\subsection{The Original Sensitivity Measurement Standards}

The initial standards are developed with 6 areas and 19 standards. The following Table 2 shows the original standards.

Table 2. The Original Selection Standards

\begin{tabular}{|c|c|}
\hline Area & lards \\
\hline General & $\begin{array}{l}\text { 1. I am interested in information and } \\
\text { communication ethics. } \\
\text { 2. I am willing to practice the recommended } \\
\text { acts of ethics in everyday life. } \\
\text { 3. I will stop immediately if I know of any } \\
\text { harmful behavior in ICT. }\end{array}$ \\
\hline Netiquette & $\begin{array}{l}\text { 4. I'm interested in netiquette } \\
\text { 5. I am willing to practice the netiquette's } \\
\text { recommended behavior in everyday life. } \\
\text { 6. I will stop immediately if I know of any } \\
\text { harmful behavior on netiquette. }\end{array}$ \\
\hline $\begin{array}{l}\text { Personal } \\
\text { Information } \\
\text { Protection }\end{array}$ & $\begin{array}{l}\text { 7. I am interested in privacy. } \\
\text { 8. I am willing to practice the recommended } \\
\text { acts for the personal information protection in } \\
\text { my daily life. } \\
\text { 9. I will stop immediately if I know of my } \\
\text { personal information violation. }\end{array}$ \\
\hline $\begin{array}{l}\text { Cop } \\
\text { Prot }\end{array}$ & $\begin{array}{l}\text { 10. I am interested in copyright protection } \\
11 \text {. I am willing to practice the recommended } \\
\text { acts for the copyright protection in my daily } \\
\text { life. } \\
\text { 12. I will stop immediately if I know of my } \\
\text { copyright violation }\end{array}$ \\
\hline $\begin{array}{l}\text { Internet } \\
\text { Addiction }\end{array}$ & $\begin{array}{l}\text { 13. I am interested in internet addiction. } \\
\text { 14. I am willing to practice the recommended } \\
\text { actions to prevent internet addiction in my } \\
\text { daily life. } \\
\text { 15. I will stop immediately if I know of an act } \\
\text { or habit that could lead to internet addiction. } \\
\text { 16. I will be treated and consulted if it turns } \\
\text { out to be an internet addiction. }\end{array}$ \\
\hline $\begin{array}{l}\text { Cyber } \\
\text { Crime }\end{array}$ & $\begin{array}{l}\text { 17. I am interested in cybercrime. } \\
\text { 18. I have a willingness to practice free } \\
\text { behavior from cybercrime in my daily life. } \\
19 \text {. I will stop immediately if I know my } \\
\text { behavior is a cybercrime. }\end{array}$ \\
\hline
\end{tabular}

\section{Statistical Analysis of the Proposed Standards}

\subsection{Overall procedure}

In order to test the reliability of the proposed standards, extensive statistical works are done. First, 30 elementary school teachers in Seoul Metropolitan area in Korea are surveyed. Their majors are all information education. They are surveyed on May and June 2019. They are supposed to answer 5 scales for each standard as follows.

$$
\begin{aligned}
& \text {-Very likely(5 point) } \\
& \text {-Slightly likely(4 point) } \\
& \text {-Average( } 3 \text { point }) \\
& \text {-Slightly not likely(2 point) } \\
& \text {-Very not likely(1 point) }
\end{aligned}
$$

\subsection{Item Analysis}

Table 3 shows the mean, standard deviation, skewness, and kurtosis of the 19 standards to measure students' sensitivity to information and communication ethics.

Table 3. Results of Item Analysis

\begin{tabular}{|l|l|l|l|l|}
\hline No & $\mathrm{M}$ & SD & Skewness & Kurtosis \\
\hline 1 & 3.93 & 1.01 & -0.50 & -0.88 \\
\hline 2 & 4.27 & 0.94 & -1.11 & 0.28 \\
\hline 3 & 4.37 & 0.96 & -1.82 & 3.80 \\
\hline 4 & 4.07 & 1.14 & -1.18 & 0.59 \\
\hline 5 & 4.37 & 0.93 & -1.38 & 1.03 \\
\hline 6 & 4.33 & 1.03 & -1.56 & 2.21 \\
\hline 7 & 4.27 & 0.91 & -0.87 & -0.42 \\
\hline 8 & 4.17 & 0.91 & -0.64 & -0.79 \\
\hline 9 & 4.27 & 1.05 & -1.35 & 1.48 \\
\hline 10 & 4.27 & 0.91 & -0.87 & -0.42 \\
\hline 11 & 4.27 & 0.87 & -0.91 & -.0 .08 \\
\hline 12 & 4.30 & 0.99 & -1.58 & 2.77 \\
\hline 13 & 4.47 & 0.90 & -1.72 & 2.18 \\
\hline 14 & 4.47 & 0.82 & -1.50 & 1.63 \\
\hline 15 & 4.57 & 0.90 & -2.67 & 8.11 \\
\hline 16 & 4.20 & 0.92 & -0.99 & 0.19 \\
\hline 17 & 3.87 & 1.14 & -0.63 & -0.98 \\
\hline 18 & 4.00 & 1.11 & -0.80 & -0.69 \\
\hline 19 & 4.17 & 1.12 & -1.31 & 1.02 \\
\hline
\end{tabular}

Where $\mathrm{M}$ means mean and SD means standard deviation

As a result of the analysis, the mean ranged from 3.87 to 4.57 and the standard deviation ranged from 0.82 to 1.14 . In addition, as a result of analyzing the skewness and kurtosis to examine the distribution of the items, the skewness range of each standard was $-0.50 \square-2.67$ and the kurtosis range was $-0.08 \square 8.11$. In general, if the absolute value of the skewness index is greater than 3.0, the skewness is severe, and if the absolute value of the kurtosis index is greater than 10 , it can be determined that there is a problem in the normal distribution. Given these criteria, the descriptive statistics and item distribution of the items to measure students' evaluation of information and communication ethics sensitivity are good.

\subsection{Reliability Analysis}

In order to verify the reliability of the items measuring the sensitivity of information and communication ethics, the results 
of analyzing the correspondence between the items using the Cronbach $\alpha$ value are shown in Table 4.

Table 4. Results of Reliability Analysis

\begin{tabular}{|c|c|c|c|}
\hline Area & $\begin{array}{l}\text { Item } \\
\text { No. }\end{array}$ & $\begin{array}{l}\text { Correlation } \\
\text { Coefficient }\end{array}$ & $\begin{array}{c}\text { Removal } \\
\text { Factor }\end{array}$ \\
\hline \multirow{3}{*}{ General } & 1 & 0.10 & 0.76 \\
\hline & 2 & 0.57 & -0.19 \\
\hline & 3 & 0.37 & 0.33 \\
\hline \multicolumn{4}{|c|}{ Cronbach's $\alpha=0.51$} \\
\hline \multirow{3}{*}{ Netiquette } & 4 & 0.44 & 0.84 \\
\hline & 5 & 0.72 & 0.53 \\
\hline & 6 & 0.62 & 0.62 \\
\hline \multicolumn{4}{|c|}{ Cronbach's $\alpha=0.75$} \\
\hline \multirow{3}{*}{$\begin{array}{l}\text { Personal } \\
\text { Information } \\
\text { Protection }\end{array}$} & 7 & 0.73 & 0.80 \\
\hline & 8 & 0.78 & 0.75 \\
\hline & 9 & 0.69 & 0.85 \\
\hline \multicolumn{4}{|c|}{ Cronbach's $\alpha=0.86$} \\
\hline \multirow{3}{*}{$\begin{array}{l}\text { Copyright } \\
\text { Protection }\end{array}$} & 10 & 0.66 & 0.88 \\
\hline & 11 & 0.88 & 0.69 \\
\hline & 12 & 0.70 & 0.85 \\
\hline \multicolumn{4}{|c|}{ Cronbach's $\alpha=0.86$} \\
\hline \multirow{4}{*}{$\begin{array}{l}\text { Internet } \\
\text { Addiction }\end{array}$} & 13 & 0.53 & 0.91 \\
\hline & 14 & 0.89 & 0.78 \\
\hline & 15 & 0.89 & 0.77 \\
\hline & 16 & 0.66 & 0.87 \\
\hline \multicolumn{4}{|c|}{ Cronbach's $\alpha=0.87$} \\
\hline \multirow{3}{*}{ Cyber Crime } & 17 & 0.62 & 0.91 \\
\hline & 18 & 0.87 & 0.67 \\
\hline & 19 & 0.73 & 0.81 \\
\hline \multicolumn{4}{|c|}{ Cronbach's $\alpha=0.86$} \\
\hline \multicolumn{4}{|c|}{ (Overall) Cronbach's $\alpha=0.94$} \\
\hline
\end{tabular}

As shown in Table 4, Cronbach $\alpha$ showed 0.51 for general, netiquette 0.75 , personal information protection 0.86 , copyright protection 0.86 , internet addiction 0.87 , cyber crime 0.86 , and overall information ethics sensitivity of 0.94 , all above 0.50 . The reliability is very good.

Table 5. Results of Correlation Analysis

\begin{tabular}{|l|c|}
\hline \multicolumn{1}{|c|}{ Area } & Correlation Value \\
\hline General & $0.796^{* * *}(0.000)$ \\
\hline Netiquette & $0.859 * * *(0.000)$ \\
\hline $\begin{array}{l}\text { Personal Information } \\
\text { Protection }\end{array}$ & $0.824 * * *(0.000)$ \\
\hline Copyright Protection & $0.881 * * *(0.000)$ \\
\hline Internet Addiction & $0.845^{* * *}(0.000)$ \\
\hline Cyber Crime & $0.781 * * *(0.000)$ \\
$* * * \mathrm{p}<.001$ &
\end{tabular}

\subsection{Correlation Analysis}

Table 5 shows the correlation between the information communication ethics sensitivity subdomain and the information communication ethics sensitivity.

Overall information and communication ethics $(r=.796, p$ $<.001)$, netiquette $(\mathrm{r}=.859, \mathrm{p}<.001)$, personal information protection $(\mathrm{r}=.824, \mathrm{p}<.001)$, copyright protection $(\mathrm{r}=.881, \mathrm{p}$ $<.001)$, internet addiction $(\mathrm{r}=.845, \mathrm{p}<.001)$, and cyber crimes $(\mathrm{r}$ $=.781, \mathrm{p}<.001)$ showed a statistically significant correlation with the overall information communication ethics sensitivity. Therefore, it can be seen that the overall information and communication ethics, which measure the sensitivity of general information and communication ethics, and netiquette, personal information protection, copyright protection, internet addiction and cybercrime are stable.

\section{Conclusions and Further Research Issues}

In the modern knowledge and information society, everyone is benefiting from advanced information techniques. However, various side effects also become a big problem. These side effects are time consuming and expensive to prevent and treat. Therefore, prevention through school education is very important.

At present, a variety of information and communication ethics education is provided to young adolescents. In addition, various measures have been developed to properly educate youth. Most scales, however, measure knowledge or will of them. Those scales do not reflect how they are sensible for information and communication ethics.

In this paper, the comprehensive measurement standards for sensitivity are developed. After the initial standards are developed, those standards are finalized through rigorous statistical analysis. Finally, 19 standards with 6 areas are proposed. These standards will be very helpful for measuring information and communication ethics sensitivity for elementary school students.

The immediate research issues are as follows. First, usability of these standards need to be tested by applying them to elementary school students. Second, it is necessary to develop extensive standards for middle school students and high school students, and adults. Recently, ethical issues for artificial intelligence are getting attention in the $4^{\text {th }}$ industrial revolution era[14,15]. In the long run, the proposed sensitivity measurement standards need to be extended for artificial intelligence and big data issues.

\section{Conflict of Interest}

The authors declare no conflict of interest.

\section{Acknowledgement}

This work was supported by the 2019 Research Fund of Seoul National University of Education

\section{References}

[1] P. Song, H. Ryou, “A Study on VR Curriculum”, Journal of Korea Internet of Things Society, 2(4), pp. 21-25, 2016. https://doi.org/10.20465/KIOTS.2016.2.4.021

[2] G. Yoo, S. Kim, "Effects of STEAM activities using VR.AR on creative problem solving ability and peer interactions of children", The Journal of 
Korea Open Association for Early Childhood Education, 24(2), pp. 525-560, 2019, http://dx.doi.org/10.20437/KOAECE24-2-20

[3] Y. Chung, "Development of VR Fire-extinguishing Experience Education Contents Using UX Design Methodology", The Journal of the Korea Contents Association, 17(3), pp. 222-230, 2017, http://dx.doi.org/10.5392/JKCA.2017.17.03.222

[4] J. Park, J. Han, "Development of Educational Contents in Robot Ethics for Elementary Students", Journal of Creative Information Culture, 4(2), pp. 143-151, 2018.

[5] E. Yoo, M. Cho, "The Ethics of Robots and Humans in the Post-Human Age", The Journal of the Korea Contents Association", 18(3), pp. 592-600, 2018, https://doi.org/10.5392/JKCA.2018.18.03.592

[6] S. Byun, H. Shin, J. Jeong, H. Kim, "A Study on Necessity of The Chart of Robot Ethics and its Contents", Journal of Ethics, 1(112), pp. 295-319, 2017, http://dx.doi.org/10.15801/je.1.112.201703.295

[7] M. Yoo, K. Shon, "Effects of Nursing Ethics Education on Biomedical Ethics Awareness, Moral Sensitivity and Moral Judgment of Nursing Students", Journal of the Korean Bioethics, 12(2), pp. 61-76, 2012.

[8] M. Park, D. Kjervik, J. Cradell, M. Oermann, "The Relationship of Ethics Education to Moral Sensitivity and Moral Reasoning Skills of Nursing Students", Nursing Ethics, 19(4), pp. 568-580, 2012, https://doi.org/10.1177/0969733011433922

[9] J. Lee, K. Han, Y. Lee, S. Kim, "Development of an Index Model on the Information and Communication Ethics", Journal of the Korean Society of Computer Education, 10(3), pp. 19-29, 2007.

[10] S. Cho, S. Kim, "Analysis of Factors to Measure Information Communication Ethics of Adolescents Using Delphi and AHP", Journal of the Korean Society of Computer Education, 11(9), pp. 1-9, 2008.

[11] S. Cho, "The Development of Scale based on TPB to Measure the Information Communication Ethics Awareness", The Journal of Curriculum and Evaluation, 15(1), pp. 291-320.

[12] I. Cho, J. Kim, "Measurement Tool Development for the Consciousness of Information and Communication Ethics", The Journal of Educational Information and Media, 15(4), pp. 107-128, 2009.

[13] K. Kim, S. Kim, "Development and Validation of the Information and Communication Ethics Index of Adolescents", The Journal of Curriculum and Evaluation, 17(3), pp. 191-221, 2014

[14] V. Dignum, "Ethics in Artificial Intelligence: Introduction to the Special Issue", Ethics and Information Technology, 20(1), pp. 1-3, 2018. https://doi.org/10.1007/s10676-018-9450-z

[15] A. Jobin, M. Lenca, and E. Vayena, "The Global Landscape of AI Ethics Guidelines", Nature Machine Intelligence, 1, pp. 389-399, 2019, https://doi.org/10.1038/s42256-019-0088-2 